\title{
Pengaruh Puasa terhadap Contrast-Media Induced Nephropathy (CIN) pada Pemeriksaan CT-Scan Setelah Pemberian Kontras Intravena
}

\author{
Undang Ruhimat, ${ }^{1}$ Atta Kuntara, ${ }^{1}$ Mariana Rosalinda Togatorop ${ }^{2}$ \\ ${ }^{1}$ Departemen Ilmu Radiologi Fakultas Kedokteran Universitas Padjadjaran Rumah Sakit Dr. Hasan Sadikin \\ Bandung, ${ }^{2}$ Mahasiswa Program Program Pendidikan Dokter spesialis Ilmu Radiologi Fakultas Kedokteran \\ Universitas Padjadjaran/Rumah Sakit Dr. Hasan Sadikin Bandung
}

\begin{abstract}
Abstrak
Pasien puasa sebelum dilakukan prosedur CT-scan dengan kontras untuk mencegah aspirasi yang mungkin terjadi akibat efek samping kontras. Puasa menyebabkan gangguan hidrasi ditambah dengan risiko nefropati yang diinduksi kontras contrast-media induced nephropathy (CIN). Peningkatan kreatinin setelah pemeriksaan dapat memprediksi timbulnya nefropati akibat kontras. Penelitian ini bertujuan mengetahui pengaruh puasa terhadap kejadian CIN. Penelitian merupakan studi deskriptif analisis dengan rancangan penelitian kasus kontrol. Subjek penelitian diambil melalui teknik consecutive random sampling pasien di Departemen Radiologi Rumah Sakit Dr. Hasan Sadikin Bandung dari bulan April-September 2012. Sebanyak 28 pasien dibagi 2 kelompok, yaitu kelompok yang mengalami peningkatan kreatinin setelah penyutikan kontras dalam 48-72 jam sebagai kelompok kasus dan kelompok yang tidak mengalami peningkatan kreatinin setelah penyuntikan kontras sebagai kelompok kontrol.Hasil penelitian menunjukkan, tidak terdapat perbedaan bermakna pada pasien puasa setelah dilakukan CT-scan dengan media kontras yang mengalami peningkatan kreatinin dan yang tidak mengalami peningkatan kreatinin $(p=0,91)$. Terdapat hubungan usia dengan CIN pada pasien yang menjalani pemeriksaan CT dengan kontras intravena $(\mathrm{p}=0,008)$, dan tidak terdapat hubungan antara lama puasa dan CIN $(\mathrm{p}=0,967)$. Simpulan, tidak terdapat pengaruh kejadian CIN pada pasien yang menjalani pemeriksaan CT-scan dengan kontras intravena pada usia muda dan terdapat pengaruh pada usia lanjut. [MKB. 2017;49(1):55-60]
\end{abstract}

Kata kunci: CT-scan, CIN, peningkatan kreatinin, puasa

\section{Effect of Fasting on the Contrast Media-Induced Nephropathy (CIN) Occurrence in CT Scan Examination after Intravenous Contrast Injection}

\begin{abstract}
Fasting before contrast enhanced CT-scan procedure is applied to prevent aspiration that may occur as a side effect of intravenous contrast. Fasting causes hydration disruption with the risk of contrast-induced nephropathy (CIN). Increased creatinine immediately after examination using contrast can predict the incidence of contrast nephropathy. The research subject was taken through consecutive random sampling technique at Department of Radiology Dr. Hasan Sadikin General Hospital Bandung from April-September 2012. This descriptive analysis study with case-control study design aimed to determine the effect of fasting on the occurrence of CIN. Subjects were recruited through consecutive random sampling technique. A total of 28 patients were divided into 2 groups: group experienced an increase in creatinine after contrast injection within 48-72 hours as the case group and the group that did not experience an increase in creatinine after intravenous contrast injection as the control group. Results showed no significant differences between fasting patients who experienced increased creatinine and who did not experience increased creatinine $(\mathrm{p}=0.910)$ after a CT scan with contrast medium There was a relationship between age and CIN in patients undergoing CT-scan with intravenous contrast $(p=0.008)$ and there was no relationship between long fasting and $\operatorname{CIN}(\mathrm{p}=0.967)$. It is concluded statistically that fasting in patients undergoing CT-scan with intravenous contrast at a young age does not affect the incidence of CIN; however, effect is seen in elderly patients. [MKB. 2017;49(1):55-60]
\end{abstract}

Key words: CT scan, CIN, fasting, increased creatinine

Korespondensi: Undang Ruhimat, dr., Sp.Rad(K), Departemen Radiologi Fakultas Kedokteran Universitas Padjadjaran/Rumah Sakit Dr. Hasan Sadikin Bandung, Jalan Pasteur No. 38 Bandung, mobile: 08122030852, e-mail: undangruhimat@gmail.com 


\section{Pendahuluan}

Contrast induced nephropathy (CIN) adalah gangguan fungsi ginjal akut, yaitu dalam waktu 48-72 jam setelah pemberian kontras intravena, dinilai dari peningkatan kreatinin serum sebesar lebih dari $25 \%$ atau $0,5 \mathrm{mg} / \mathrm{dL}$. Penyebab gangguan fungsi ginjal belum diketahui pasti, terdapat beberapa faktor risiko terjadi CIN, salah satunya adalah keadaan dehidrasi. Pada prosedur CT-scan pemeriksaan dengan kontras dicantumkan bahwa harus dilakukan persiapan puasa selama 6 jam. Hal ini diduga mengganggu status hidrasi pasien dan menyebabkan pasien memiliki faktor risiko terjadi nefropati akibat kontras. Penelitian ini bertujuan mengetahui apakah terdapat hubungan lama puasa dengan peningkatan kreatinin pada pasien rawat jalan yang akan menjalani pemeriksaan CT-scan dengan kontras intravena.

Seiring dengan ada teknologi yang semakin maju dan juga penggunaan alat CT-scan, upaya peningkatan kualitas pencitraan juga semakin berkembang. Terdapat berbagai aplikasi terkait hal ini, salah satunya adalah dengan pemberian media kontras secara intravena. Sekitar 43\% pemeriksaan CT-scan melibatkan penggunaan media kontras yang diberikan secara intravena. ${ }^{1}$

Di Amerika Serikat pada tahun 2007 dilakukan sekitar 68,7 juta pemeriksaan CT-scan 50\% pemeriksaan ini dilakukan menggunakan media kontras sehingga diperkirakan sekitar 34 juta dosis media kontras diberikan pada tahun 2007. Dari penggunaan kontras tersebut, sebanyak $80 \%$ sampai $90 \%$ media kontras digunakan untuk pemeriksaan CT-scan dan sekitar 10-20\% untuk prosedur kateterisasi jantung. Angka kejadian CIN ini telah menjadi penyebab ketiga terbesar gagal ginjal akut yang didapat di rumah sakit, terhitung $12 \%$ dari semua kasus. Risiko CIN terus berkembang dengan penggunaan media kontras pada pasien-pasien dengan risiko tinggi.

Peningkatan pemeriksaan dengan CT-scan serta penggunaan media kontras, baik dalam hal diagnostik maupun terapi dapat memberikan tantangan yang baru terhadap efek secara klinis dalam pemeriksaan radiologi. Dalam kondisi fisiologis normal hampir seluruh media kontras dieksresikan melalui ginjal. Media kontras akan mulai dieksresikan oleh ginjal dalam waktu setengah jam setelah dilakukannya pemberian kontras secara intravena. Konsentrasi yang dicapai pada sistem tubulus ginjal kurang atau sama dengan 100 kali konsentrasi media kontras dalam plasma dan mencapai kurang atau sama dengan 30\% dari kontras yang diinjeksikan. Keadaan inilah menyebabkan toksisitas kontras yang cukup tinggi pada ginjal. Gangguan fungsi ginjal akut setelah penggunaan media kontras intravena pada saat ini telah didokumentasikan sebagai salah satunya komplikasi penggunaan media kontras. ${ }^{1}$

Contrast media induced nephropathy (CIN) atau nefropati yang diinduksi media kontras dengan cara signifikan sudah menjadi sumber morbiditas serta mortalitas di rumah sakit sejalan dengan peningkatan penggunaan media kontras yodium intravena dalam pemeriksaan pencitraan diagnostik dan prosedur intervensi terutama pada pasien berisiko tinggi. ${ }^{2,3}$ CIN merupakan penyebab terbanyak ketiga gagal ginjal akut iatrogenik setelah tindakan bedah dan hipotensi. ${ }^{2}$

Secara fisiologi normal sekitar $80 \%$ konsumsi oksigen ginjal digunakan untuk aktivitas $\mathrm{Na}+-$ $\mathrm{K}+$-ATPase sehingga dehidrasi, pengurangan konsumsi garam, dan hipoperfusi ginjal akan menyebabkan medula mengabsorbsi natrium yang dapat mengakibatkan konsumsi oksigen bertambah dan peningkatan risiko hipoksia. ${ }^{2}$ Keadaaan hipoksia jaringan, kemudian disertai pemberian media kontras juga mempunyai sifat toksik pada parenkim ginjal merupakan faktor risiko terjadi nefropati kontras.

Standar prosedur pemeriksaan CT-scan di beberapa rumah sakit dinyatakan bahwa pasien diminta untuk melakukan puasa persiapan dengan dengan durasi waktu yang bervariasi antara 3 sampai 6 jam sebelum pemeriksaan.,3 Alasan utama dilakukan puasa dikarenakan penyuntikan kontras secara intravena terhadap beberapa pasien mampu menyebabkan rasa mual dan muntah. Hal ini dapat menyebabkan aspirasi dan mengganggu proses pemeriksaan. Dalam standar prosedur pemeriksaan CT-scan di Rumah Sakit Dr. Hasan Sadikin Bandung, pasien yang akan melaksanakan pemeriksaan CT-scan dengan media kontras intravena diminta untuk melakukan puasa 6 jam sebelum pemeriksaan. ${ }^{2}$ Puasa selain dapat menyebabkan keadaan yang dehidrasi juga dapat menginduksi hiperglikemia. ${ }^{1}$ Keadaan ini merupakan faktor risiko nefropati yang diinduksi kontras. ${ }^{4}$

Sampai saat sekarang ini belumlah ada penelitian mengenai hubungan lama puasa dengan peningkatan kadar kreatinin serum pada pasien yang menjalani pemeriksaan CT-scan dengan kontras intravena. Hasil penelitian ini diharapkan dapat dipakai sebagai pertimbangan dokter ahli radiologi untuk menentukan lama dilakukan puasa persiapan pada pasien yang 
akan menjalani pemeriksaan CT-scan dengan media kontras secara intravena. Penelitian ini bertujuan mencegah CIN pada pasien yang dilakukan CT-scan dengan media kontras.

\section{Metode}

Penelitian ini merupakan studi deskriptif analitik dengan rancangan penelitian kasus kontrol. Penelitian berjalan dengan persetujuan Komite Etik Rumah Sakit Dr. Hasan Sadikin Bandung.

Pengambilan sampel penelitian sebanyak 28 pasien di Departemen Radiologi Rumah Sakit Dr. Hasan Sadikin Bandung bulan April-September 2012. Pemeriksaan CT-scan menggunakan media kontras non ionik hipoosmolar secara intravena dipilih secara acak (randomized) berdasar atas urutan datang pasien (consecutive sampling), yaitu semua subjek yang memenuhi kriteria sampai jumlah sampel terpenuhi

Dilakukan pengumpulan hasil laboratorium dari pemeriksaan serum kreatinin sebelum dan 48 sampai 72 jam sesudah pemeriksaan CT pada pasien puasa yg diberikan media kontras

\section{Hasil}

Subjek pada penelitian ini adalah pasien yang menjalani pemeriksaan CT-scan dengan media kontras non ionik hipoosmolar yang diberikan secara intravena

Karakteristik subjek penelitian ini berdasar atas usia dan jenis kelamin pada pasien yang sudah menjalani pemeriksaan CT-scan dengan media kontras intravena pada kelompok yang mengalami peningkatan kreatinin dan kelompok kontrol (Tabel 1). Terdapat perbedaan bermakna subjek berdasar atas usia pada pasien yang menjalani pemeriksaan CT-scankelompok yang mengalami peningkatan kreatinin bila dibanding dengan kelompok kontrol $(\mathrm{p}<0,001)$. Tidak terdapat perbedaan bermakna jenis kelamin pasien yang menjalani pemeriksaan CT-scan pada kelompok yang mengalami peningkatan kreatinin dibanding dengan kontrol dengan nilai $(\mathrm{p}=1,000)$.

Tidak terdapat perbedaan bermakna lama puasa pasien yang menjalani CT-scan antara kelompok yang sudah mengalami peningkatan kreatinin dan kontrol ( $p=0,910)$ (Tabel 2).

Tabel 3 telah memperlihatkan peningkatan kreatinin bila dibanding dengan awal meningkat sebesar 0,07. Tabel 4 terlihat tidak terdapat perbedaan bermakna kadar kreatinin serum awal pada pasien yang menjalani pemeriksaan CT-scan antara kelompok kasus dan kelompok kontrol di Rumah Sakit Dr. Hasan Sadikin Bandung $(p=0,301)$. Terdapat perbedaan

Tabel 1 Karakteristik Subjek Penelitian berdasar atas Usia dan Jenis Kelamin pada Pasien yang Menjalani Pemeriksaan CT-scan dengan Media Kontras Intravena pada Kelompok yang Mengalami Peningkatan Kreatinin dan Kelompok Kontrol

\begin{tabular}{lccc}
\hline \multirow{2}{*}{ Usia dan Jenis Kelamin } & \multicolumn{2}{c}{ Kelompok } & \multirow{2}{*}{ Nilai p } \\
\cline { 2 - 3 } & Kasus (n=14) & Kontrol (n=14) & \\
\hline Usia (tahun) & & & $\left.<0,001^{*}\right)$ \\
$\quad$ Rata-rata(SD) & $61,21(6,27)$ & $36,07(43-70)$ & \\
Median (Rentang) & $62,50(6,27)$ & $39,00(16-55)$ & \\
$17-20$ & 0 & 4 & \\
$21-30$ & 0 & 1 & \\
$31-40$ & 0 & 3 & \\
$41-50$ & 1 & 3 & \\
$51-60$ & 3 & 3 & \\
$61-70$ & 10 & 0 & \\
Jenis kelamin & & & \\
Laki-laki & 7 & 6 & \\
Perempuan & 7 & 8 & \\
\hline
\end{tabular}

${ }^{*}$ chi-square test 
Undang Ruhimat: Pengaruh Puasa terhadap Contrast-Media Induced Nephropathy (CIN) pada Pemeriksaan CT-Scan

Tabel 2 Perbandingan lama Puasa Pasien yang Menjalani Pemeriksaan CT-scan antara Kelompok yang Mengalami Peningkatan dan Kelompok Kontrol

\begin{tabular}{lccc}
\hline \multirow{2}{*}{ Lama Puasa } & \multicolumn{2}{c}{ Kelompok } & \multirow{2}{*}{ Nilai p } \\
\cline { 2 - 3 } & Kasus (n=14) & Kontrol (n=14) & \\
\hline \multirow{2}{*}{$4-<6$ jam } & 4 & 5 & $\left.0,910^{*}\right)$ \\
6-8 jam & 7 & 6 & \\
$>8$ jam & 3 & 3 & \\
\hline
\end{tabular}

${ }^{*}$ chi square test

Tabel 3 Perbandingan Kadar Kreatinin Serum Awal dan Akhir pada Pasien yang Menjalani Pemeriksaan CT-scan dan Mengalami Peningkatan Kadar Kreatinin

\begin{tabular}{lccc}
\hline \multirow{2}{*}{ Kadar Kreatini } & \multicolumn{2}{c}{ Pengukuran } & \multirow{2}{*}{ Nilai p } \\
\cline { 2 - 3 } & Awal & Akhir & \\
\hline Rata-rata (SD) & $0,80(0,238)$ & $\left.0,001^{*}\right)$ \\
Median (rentang) & $0,74(0,60-1,55)$ & $0,79(0,65-1,99)$ & \\
\hline
\end{tabular}

${ }^{*}$ Wilcoxon sign rank test

bermakna kadar kreatinin serum akhir pada pasien yang menjalani pemeriksaan CT-scan antara kelompok kasus dan kelompok kontrol di RSUP Dr. Hasan Sadikin Bandung ( $\mathrm{p}=0,048)$.

Tabel 5 memperlihatkan median peningkatan kadar kreatinin serum paling tinggi pada pasien yang menjalani pemeriksaan CT-scan dan lama puasa 6-8 jam sebesar 0,02, namun tidak terdapat hubungan antara lama puasa dengan peningkatan kreatinin pada pasien yang menjalani CT-scan $(p=0,967)$. Tabel 6 menunjukkan peningkatan kadar kreatinin serum paling tinggi ada pada kelompok usia 51-60 tahun sebesar 0,02 dan meningkat lagi pada kelompok usia 61-70 tahun sebesar 0,02 dan hasil uji statistik menggunakan uji Kruskall Wallist pada derajat kepercayaan 95\%, menunjukkan hubungan antara usia dan peningkatan kreatinin.

\section{Pembahasan}

Berdasar atas data hasil penelitian pada Tabel 1, kelompok pasien yang mengalami peningkatan kreatinin berkisar antara usia 41 tahun sampai 70 tahun dengan kelompok usia terbanyak terjadi pada kelompok usia 61 tahun sampai 70 tahun, yaitu sebanyak 10 dari 14 orang, sedangkan pada kelompok yang tidak mengalami peningkatan kreatinin pada usia 14 tahun sampai 60 tahun,

Tabel 4 Perbandingan Kadar Kreatinin Serum Awal dan Akhir pada Pasien yang Menjalani Pemeriksaan CT-scan antara Kelompok yang Mengalami Peningkatan Kadar Kreatinin dengan Kelompok Kontrol

\begin{tabular}{lccc}
\hline \multirow{2}{*}{ Kadar Kreatin } & \multicolumn{2}{c}{ Kelompok } & Nilai p \\
\cline { 2 - 3 } & Kasus (n=14) & Kontrol (n=14) & $\left.0,301^{*}\right)$ \\
\hline Awal & $0,800(0,230)$ & $0,717(0,167)$ & \\
$\quad$ Rata-rata (SD) & $0,740(0,60-1,55)$ & $0,690(0,49-1,02)$ & $\left.0,048^{* *}\right)$ \\
Median (Rentang) & & & \\
Akhir & $0,871(0,338)$ & $0,697(1,172)$ & \\
$\quad$ Rata-rata (SD) & $0,790(0,65-1,99)$ & $0,675(0,48-1,00)$ & \\
Median (Rentang) & &
\end{tabular}

\footnotetext{
${ }^{*}$ uji Mann Whitney
} 
Undang Ruhimat: Pengaruh Puasa terhadap Contrast-Media Induced Nephropathy (CIN) pada Pemeriksaan CT-Scan

Tabel 5 Hubungan lama Puasa dengan Peningkatan Kreatinin pada Pasien yang Menjalani Pemeriksaan CT-scan dengan Media Kontras

\begin{tabular}{|c|c|c|c|c|}
\hline \multirow{2}{*}{ Kadar Kreatin } & \multicolumn{3}{|c|}{ Lama Puasa } & \multirow{2}{*}{ Nilai p } \\
\hline & $4-<6$ jam & 6-8 jam & $>8$ jam & \\
\hline Awal & & & & $0,126^{*}$ \\
\hline Rata-rata (SD) & 0,15 & 0,24 & 0,16 & \\
\hline Median (Rentang) & 0,71 & 0,76 & 0,63 & \\
\hline Akhir & & & & $\left.0,251^{*}\right]$ \\
\hline Rata-rata (SD) & 0,17 & 0,35 & 0,17 & \\
\hline Median (Rentang) & 0,73 & 0,79 & 0,68 & \\
\hline Kenaikan & & & & $\left.0,967^{*}\right)$ \\
\hline Rata-rata (SD) & 0,02 & 0,12 & 0,04 & \\
\hline Median (Rentang) & 0,00 & 0,02 & 0,01 & \\
\hline
\end{tabular}

${ }^{*}$ Kruskall Wallist test

dengan usia terbanyak pada kelompok usia 14 sampai 20 tahun, yaitu sebayak 4 dari 14 orang. Hal ini sesuai dengan karakteristik subjek pada penelitian bahwa subjek penelitian berdasar atas usia cukup luas, yaitu usia 13 tahun sampai 94 tahun. Berdasar atas usia perbedaan bermakna antara kelompok yang mengalami peningkatan kreatinin dan kelompok yang tidak mengalami peningkatan kreatinin. Sebagian besar kelompok yang mengalami peningkatan kreatinin adalah pada kelompok usia yang lanjut. Hal ini sesuai dengan teori yang menyatakan bahwa usia lanjut merupakan faktor risiko terjadi nefropati kontras. ${ }^{4,5}$

Karakteristik subjek penelitian ini berdasar atas jenis kelamin mempunyai distribusi yang hampir seimbang, tidak terdapat perbedaan bermakna antara laki-laki dan perempuan yang menjalani pemeriksaan CT-scan dengan media kontras intravena, baik pada kelompok yang mengalami peningkatan kreatinin maupun pada kelompok kontrol. Hal ini sedikit berbeda dengan penelitian didapatkan bahwa laki-laki lebih banyak mengalami nefropati kontras dibanding dengan perempuan. Ribichini dkk. $^{6}$ di dalam penelitiannya juga menemukan bahwa kejadian nefropati juga lebih banyak terjadi pada laki-laki, namun perbedaan tidak bermakna.

Bedasar atas data hasil penelitian mengenai lama puasa antara pasien yang telah mengalami peningkatan kreatinin dan kontrol pada Tabel 3, diketahui bahwa tidak terdapat perbedaan yang bermakna antara kedua kelompok pasien. Penelitian ini menunjukkan bahwa pasien pada umumnya menjalani puasa lebih dari 4 jam tidak sesuai dengan waktu yang ditentukan oleh

Tabel 6 Hubungan Usia dengan Peningkatan Kreatinin pada Pasien yang Menjalani Pemeriksaan CT-scan dengan Media Kontras Intravena

\begin{tabular}{|c|c|c|c|c|c|c|c|}
\hline \multirow{2}{*}{ Kadar Kreatin } & \multicolumn{6}{|c|}{ Usia (tahun) } & \multirow{2}{*}{ Nilai p } \\
\hline & 18-20 & $21-30$ & $31-40$ & 41-50 & $51-60$ & 61-70 & \\
\hline Awal & & & & & & & $\left.0,067^{*}\right)$ \\
\hline Rata-rata (SD) & 0,05 & 0 & 0,18 & 0,06 & 0,11 & 0,29 & \\
\hline Median (Rentang) & 0,56 & 1,02 & 0,74 & 0,74 & 0,75 & 0,76 & \\
\hline Akhir & & & & & & & $0,037^{*}$ \\
\hline Rata-rata (SD) & 0,06 & 0 & 0,17 & 0,07 & 0,11 & 0,41 & \\
\hline Median (Rentang) & 0,50 & 0,99 & 0,72 & 0,74 & 0,79 & 0,79 & \\
\hline Kenaikan kadar kreatinin & & & & & & & $0,008^{*}$ \\
\hline Rata-rata (SD) & 0,03 & 0 & 0,00 & 0,05 & 0,02 & 0,13 & \\
\hline Median (Rentang) & $-0,03$ & $-0,03$ & $-0,02$ & $-0,01$ & 0,02 & 0,04 & \\
\hline
\end{tabular}

${ }^{*}$ uji Kruskall Wallist 
prosedur pemeriksaan CT-scan dengan media kontras.

American Society of Anaesthesiology (ASA), menyatakan puasa pada tindakan invasif yang tidak menggunakan premedikasi guna mencegah aspirasi cukup selama 2 jam. $^{7}$ Tidak terdapat perbedaan bermakna kadar kreatinin awal pada kelompokyang mengalami peningkatan kreatinin dengan kelompok kontrol. Pada kelompok yang mengalami peningkatan kreatinin, kadar kretinin awal rata-rata adalah 0,80 dan kadar kreatin akhir rata-rata adalah 0,87 . Terdapat kenaikan kreatinin bermakna pada kelompok ini. Pada kelompok yang tidak mengalami peningkatan kreatinin, kadar kreatinin awal rata-rata adalah 0,72 dan kadar kreatinin akhir rata-rata adalah 0,69 . Tidak terdapat kenaikan kreatinin pada kelompok ini. Hal ini sesuai dengan teori bahwa kejadian nefropati kontras sangat jarang pada pasien dengan fungsi ginjal normal, yaitu 3,3\%. Fungsi ginjal pada kedua kelompok pasien masih dalam batas normal dan kenaikan kreatinin yang terjadi pada kelompok kasus juga masih dalam batas fungsi ginjal yang normal kenaikan kreatinin yang terjadi tidak mencapai 25\% dari nilai awal atau mencapai $0,5 \mathrm{mg} / \mathrm{dL}$ sehingga pasien tidak memenuhi kriteria CIN. Hal ini sesuai dengan penelitian yang menyatakan bahwa media kontras non-ionik hipoosmolar yang digunakan dalam penelitian ini aman pada ginjal dan dapat ditoleransi baik oleh tubuh., ${ }^{4,5}$,

Hasil penelitian, tidak terdapat hubungan yang bermakna lama puasa dengan peningkatan kreatinin. Hal ini sesuai dengan penelitian yang di lakukan oleh Tippins dkk. Ribbichini dkk., ESUR, CAR dan ACR Cochran dkk., bahwa pasien dengan fungsi ginjal yang normal sangatlah jarang mengalami nefropati yang diinduksi oleh media kontras. Selain itu, kontras non-ionik hiposmolar yang digunakan juga memiliki sifat toksik yang minimal terhadap ginjal ${ }^{4,}, 10$.

Peningkatan kreatinin terbanyak terjadi pada kelompok usia 61 tahun sampai 70 tahun. Hal ini sesuai dengan penelitian yang di lakukan oleh Tippins dkk., Ribbichini dkk. ${ }^{6}$ ESUR, CAR dan ACR Cochran dkk. yang menyatakan bahwa usia lanjut adalah salah satu faktor risiko terjadi nefropati kontras seperti pada beberapa literatur penelitian. ${ }^{4,9,10}$

Simpulan, lama pasien yang melakukan puasa sebelum dilakukan pemeriksaan CT-scan dengan media kontras intravena tidak berhubungan dengan peningkatan kadar kreatinin pada pasien sesudah dilakukan pemeriksaan CT-scan di RS
Dr. Hasan Sadikin Bandung. Terdapat hubungan usia dengan peningkatan kreatinin pada pasien yang menjalani pemeriksaan CT-scan dengan media kontras intravena. Subjek penelitian yang menjalani pemeriksaan CT-scan dengan media kontras intravena berdasar atas jenis kelamin tidak berbeda antara kelompok yang mengalami peningkatan kreatinin dan kelompok kontrol.

\section{Daftar Pustaka}

1. Katzberg RW. Contrast-induced nephropathy in 2010 [diunduh 7 Oktober 2012.] Tersedia dari http://www.appliedradiology.com/ Issues /2010/09/Articles/AR_0910_ Katzberg/Contrast-induced-nephropathyin-2010.aspx.

2. Weisbord SD, Palevsky PM. Prevention of contrast-induced nephropathy with volume expansion. Clin J Am Soc Nephrol. 2008;3(1):273-80.

3. Ningrum NR, Yuniadi Y. Contrast induced nephropathy. J Kardiologi Indonesia. 2009;30(2):71-9.

4. Lefèvre T. Strategies for managing contrastinduced nephropathy. Intervent Cardiol. 2011;6(2):124-7.

5. Workeneh BT. Acute renal failure [diunduh 2 Juli 2012]. Tersedia dari: http://emedicine. medscape.com/article/243492-overview.

6. Ribichini F, Graziani M, Gambaro G, Pasoli P, Pighi M, Abaterusso C, dkk. Early creatinine shifts predict contrast-induced nephropathy and persistent renal damage after angiography. Am J Med. 2010;123(8):75563.

7. De Aguilar-Nascimento JE, Perrone F, de Assunção Prado LI. Preoperative fasting of 8 hours or 2 hours: what does evidence reveal?. Rev Col Bras Cir. 2009;36(4):344-6.

8. Mautone A, Brown JR. Contrast-induced nephropathy in patients undergoing elective and urgent procedures. J Compilation Wiley Periodical. 2010;23(1):78-85.

9. WongPCY,LiZ,GuoJ,ZhangA.Pathophysiology of contrast-induced nephropathy. Int J Cardiol. 2012;158(2):186-92.

10. Nough H, Eghbal F, Soltani M, Nejafi F, Falahzadeh H, Faze Hl, dkk. Incidence and main determinants of contrast-induced nephropathy following coronaryangiography or subsequent balloon angioplasty. Cardiorenal Med. 2013;3(2):128-35. 